\title{
WEBER, Beatriz Teixeira. As artes de curar: medicina, religião, magia e positivismo na República Rio-Grandense - 1889-1928.
}

Anny Jackeline Torres Silveira Coltec - UFM G, D outoranda UFF

Santa M aria: Ed. da U FM S; Bauru: EDUSC, 1999, 249 pp.

O final do século XX reservou descobertas surpreendentes no campo do conhecimento médico, tanto na área da identificação como no tratamento dos males que atingem o corpo de homens e mulheres. 0 anúncio do mapeamento da seqüência dos genes que compõem o DNA humano, realizado durante a última década pelos pesquisadores do consórcio público internacional Projeto GenomaH umano (PGH), tem sido tratado como a maior conquista da área médica, inaugurando mesmo uma nova era do conhecimento sobre a humanidade. Alguns afirmam que a medicina aproxima-se agora das ciências exatas, pela precisão com a qual esta descoberta poderá municiar o saber mé dico na identificação e solução das doenças'.

Estamos cada vez mais próximos de uma visão de doença pautada exclusivamente por uma explicação científica, em que os exames realizados por equipamentos ultra-modernos e o recurso à bioquímica responderiam a todas as necessidades e enfermidades do corpo humano? Não há como negar que tal desco berta representa uma grande vitória da medicina laboratorial, pautada no desenvolvimento da técnica e da tecnologia que envolve as descobertas do que se convencionou chamar a "era bacteriológica". Porém, notícias como estas tendem a reforçar no imaginário social uma visão homogeneizadora e evolucionista do saber médico e de suas práticas. É sobre um mundo bastante contraposto a tal visão que nos fala o livro de Beatriz Weber, As artes decurar.

Elegendo como espaço de pesquisa a sociedade do Rio Grande do Sul na passagem do século XIX para o XX, a autora examina aspectos variadose interligados que caracterizariam a história do saber médico nesta região. Dentre eles, podemos citar as diferentes práticas de cura a que recorria sua população, a luta pela constituição de um campo profissional pelos médicos diplomados, as interferências que a ideologia positivista exerceu no reconhe- 
cimento da profissão, o papel da religião, da caridade e da magia na percepção da doença pelos leigos e sua interferência na posição que era assumida pelos médicos diante das mesmas. Sua análise aponta para uma realidade na qual práticas,saberes e crenças, diversos em seus fundamentos e procedimentos, partilhavam de forma às vezes conflituosa, às vezes em sobreposição ou harmonia, um mesmo espaço de ação.

Segundo Beatriz Weber, o poder da medicina é fruto de um processo que foi sendo construído durante todo o século XIX, e vai se consolidar no Rio Grande do Sul apenas por volta da década de quarenta. A teoria positivista e a forma como a medicina era por ela encarada tiveram papel importante neste processo. Conforme a autora, o positivismo era uma marca na formação das elites políticas do Rio Grande Sul e interferiu nas reações do poder público às tentativas de parte do corpo médico em criar restrições ao exercício de sua prática profissional, à adoção de medidas de interven ção para evitar a propagação das doenças e àquelas relativas à organização do espaço e da higiene urbana.

Bastante interessante éa descrição que a autora efetua sobre o modo como o saber médico é percebido por Comte e pel os partidários do positivismo, especial mente a idéia de que a medicina está subordinada à moral e à imagem que aproxima o médico do sacerdote: "aquele que diz o que é preciso fazer e o que se pode esperar, que traz a resignação em nome de uma ordem superior quando a ação não pode modificá-la" (p. 36). Havia, no Rio Grande do Sul, vários médicos partidários do positivismo. No entanto, nem todos partilhavam completamente das proposições dos seus teóricos a respeito do saber e da prática médica, mostrando, assim, como são variadas as possibilidades de apropriação das teorias que circulavam naquele momento, com leituras específicas dentro de contextos determinados.

Sobre este aspecto, chamam a aten ção as justificativas elaboradas pelos membros do A postolado Positivista do Brasil a respeito da defesa da liberdade no exercício da arte de curar. 0 profissional desta arte devia exercer uma influência espiritual sobre seus pacientes, era preciso que o médico se esforçasse para conquistar sua confiança. Era através dela, somada à sua conduta e ao seu devotamento, que o médico imporia a autoridade de sua palavra, e não por uma reserva de mercado estabel ecida pela lei ou pela força. Antes de criticar os empíricos, dos quais teria nascido, a medicina (dita científica) devia apropriar-se dos seus resultados que foram confirmados pela experiência. Além disto, a confiança angariada pelos práticos e empíricos junto à população era fruto de uma identidade de crenças por eles partilhada, de concepções de mundo muito mais próximas do que, por exemplo, as que seriam professadas e propostas pelos médicos diplomados. M iguel Lemos, do A postolado 
Positivista, contrapunha a figura do médico moderno aos seus "primitivos confrades, que sabem sinceramentefazer partilhar aos seus doentes a confiança que eles têm nos meios que empregam" (p.43). Este fator tal vez também explicasse o sucesso de muitos "charlatães indignos". À ciência, dizia então, era necessário penetrar no espírito da população para ser aceita.

A autora aborda também as relações entre as crenças positivistas e as questões da higiene e da intervenção pública nos espaços urbanos,e a influência que as teorias científicas sobre o contágio/transmissão (miasmas, bacteriologia) exerceram sobrea administração gaúcha, marcada pela ação de políticos positivistas.Ela frisa que, muitasvezes, concepçõesteóricas diferenciadas eram agregadas pelas instituições públicas, assim como pelos próprios médicos. Isto põe em cheque a perspectiva evolucionista e triunfalista do conhecimento científico, pautado por conquistas cada vez mais amplas e por uma aproximação sempre maior com a verdade. E não eram só filiações a abordagens distintas sobre a doença e a cura - muitas das quais na época eram consideradas "científicas", como o espiritismo e a homeopatia, entre outros que caracterizavam os médicos do período. Havia as crenças de caráter "subjetivo", como a própria religião, que também marcava a prática de muitos desses profissionais.

Beatriz Weber aborda ainda o processo de constituição de "uma solidariedade corporativa e de um consenso profissional" entre os médicos diplomados. Isto se faz através de instituições como hospitais, associações ou entidades profissionais e da própria Faculdade de Medicina. Porém, como mostra a autora, este não é um processo linear ou simples, mas um caminho conflituoso marcado por desavenças políticas e filosóficas. Ao mostrar que estes médicos não eram os únicos portadores de um saber sobre as doenças ea cura; que seu conhecimento era marcado por incertezas teóricas, além das dificuldades práticas (como o instrumental precário, por exemplo); que participavam de outras crenças, como a religião, que influíam na forma como viam o processo de cura e seu próprio papel como profissionais, a autora desmistifica mais uma vez a velha imagem gloriosa e triunfante da medicina ea noção de que a constituição do poder que este saber exerce sobre a sociedade tenha sido fruto de um projeto homogêneo e sempre vitorioso.

Faz parte, ainda, da sua análise, o papel desempenhado pela Santa Casa de M isericórdia no processo de formação de um campo de saber específico, a transformação de suas funções assistênciais em terapêuticas e de produção de conhecimento, e as tensões que eram criadas pela convivência de práticas e saberes distintos. Por fim, Beatriz Weber mostra a permanência, durante todo este processo de afirmação do saber médico "científico", das outras diversas práticas de cura às quais recorriam os diferentes grupos sociais. Nesta par- 
te, a autora enfatiza uma perspectiva de análise que toma os grupos populares como sujeitos atuantes na organização do mundo no qual viviam, superando as interpretações que vão apresentar estes grupos como meros objetos ou pacientes de um projeto denormatização (neste caso, de "medicalização" da sociedade), ou que encaram suas ações apenas como uma reação à imposição destas normas disciplinadoras e dominadoras. Conforme afirma Beatriz Weber, estes setores sociais "interagi ram socialmente com criatividade e participaram ativamente das definições do mundo em que viveram"(p.18).

Em sua conclusão, a autora nos diz que

(...) as diversas formas de organização para a cura ... não se impuseram inclementes umas sobre as outras, garantindo o predomínio de uma visão. Intercambiaram-se el ementos entre as concepções, compondo universos explicativos próprios, muitas vezes ambíguos e contraditórios ... M uitas desenvolveram formas de atuação que as mantiveram em atividade até hoje. (p.228).

Isto nos leva a pensar sobre as afirmações emitidas pela imprensa sobre a conquista representada pela descoberta do código genético humano, apresentadas no início deste texto. Será mesmo tão absoluto o triunfo identificado nesta conquista? Como têm reagido as pessoas comunsa este avanço anunciado? 0 que muda na sua perspectiva sobre a doença e o processo da cura? Será que esta descoberta vai fazer esvaziar a peregrinação de pacientes que procuram o "Lar São Luiz", o Centro do médium Chico Xavier² e outras diversas "casas de cura", terreiros de umbanda ou benzedeiras que se espalham através do País? Vamos deixar de lado os velhos chás para o resfriado, a enxaqueca ou outro mal-estar qualquer?

A feição que tem tomado o noticiário a respeito destas descobertas se inscreve na tradição, apontada por M aria Clementina P Cunha na apresentação da obra em exame, que

(...) atribui ao saber [especialmente ao saber dito científico], com sua intrínseca pretensão de deter a verdade, um potencial quase ilimitado de controlar e moldar a sociedade segundo seus próprios desígnios (p.15).

Se a genética promete à sociedade grandes conquistas, ela também apresenta fracassos e erros - que, porém, não encontram publicidade tão marcante nos meios de comunicação. Além disto, ela propõe questões de caráter ético que afetam to da a sociedade e que, portanto, não deverão ser decididas num âmbito cultural,social e político restrito, como até então tem sido feito. É preciso, como nos mostra o livro em exame, ultrapassar a imagem assépti- 
ca da medicina [e da ciência como um todo] que lança fora toda crença, toda subjetividade, toda diversidade que fundamentou este saber e suas práticas sobre a cura. A ciência não é tão poderosa e hegemônica como muitas vezes deixa transparecer, nem homens e mulheres vivem ou elaboram o seu cotidiano a partir de uma perspectiva exclusivamente científica, de uma visão de mundo informada apenas pel os saberes que compõem esta esfera da produção cultural da sociedade. A leitura de Beatriz Weber contribui deforma significativa para ultrapassarmos essa visão linear e progressista que ainda hoje marca a imagem do conhecimento científico.

\section{NOTAS}

1" "0] Projeto Genoma Humano, promete a era da bio-medicina de precisão"; "A transcrição ... do código genético inaugura a era da medicina como ciência quase exata". Folha de S. Paulo, "Genoma" (Caderno Especial). São Paulo, 27 de junho de 2000.

2 O "Lar São Luiz" e o centro de Chico Xavier são conhecidas "casas de cura" que realizam consultas e operações espirituais. A primeira está localizada no Rio de Janeiro, e a segunda, em M inas Gerais. 